\title{
AUDIT SISTEM INFORMASI AKADEMIK BERBASIS WEB MENGGUNAKAN FRAMEWORK COBIT 5.0 PADA DOMAIN APO13 DAN DSS05
}

\author{
(Resume) \\ Tubagus Akbar Hafizd \\ 195100008P, Sistem Informasi \\ Fakultas Komputer \\ tubagusakbar.student@umitra.ac.id
}

\begin{abstract}
Universitas Mitra Indonesia adalah perguruan tinggi swasta yang berdiri didalam naungan Yayasan Pendidikan Umitra yang berdomisili di Kota Bandar Lampung. Saat ini perguruan telah menerapkan sistem dan teknologi informasi dalam mendukung operasional akademik yang dilaksanakan oleh Divisi IT.

Tetapi, terdapat beberapa kekurangan dalam penerapan tersebut khususnya dalam hal keamanan seperti security incident. Untuk mencegah hal-hal tersebut terjadi lagi, maka perlu diketahui sejauh mana tata kelola sistem keamanan teknologi informasi perguruan tinggi dengan cara melakukan perbaikan, karena dengan adanya perbaikan dapat dihasilkan rekomendasi berupa tindakan-tindakan apa yang harus dilakukan agar hal-hal tersebut tidak terjadi lagi. Sehingga penelitian dilakukan untuk mengetahui Capability Level pada tata kelola sistem keamanan teknologi informasi Universitas Mitra Indonesia dengan menggunakan framework COBIT 5.0 domain proses APO13 dan DSS05.

Hasil penelitian menunjukan Capability Level pada domain proses APO13.01,02,03 dan DSS05.01,02,03,04,05,06,07, berada pada level 1, sedangkan Capability Level yang diinginkan pada kedua domain proses adalah level 2, sehingga terdapat gap sebesar 1. Setelah mengetahui Capability Level saat ini dan yang diinginkan dapat diberikan rekomendasi untuk perbaikan suatu system.
\end{abstract}

Kata Kunci : Keamanan, framework COBIT 5, evaluasi tata kelola 


\section{A. PENDAhuluan}

A. Teknologi Informasi (TI) menjadi salah satu kebutuhan yang sangat penting bagi suatu organisasi saat ini, karena dengan adanya teknologi informasi dapat membantu perusahaan dalam meningkatkan efisiensi dan efektifitas dari proses bisnis perusahaan itu sendiri, penerapan teknologi informasi diperlukan juga sebagai alat bantu dalam upaya memenangkan persaingan, tidak hanya dalam dunia bisnis, tetapi juga dalam dunia pendidikan perguruan tinggi.

B. Perkembangannya, teknologi informasi yang dibangun dan dikelola masih dioperasikan secara terpisah oleh masingmasing unit fungsi organisasi.

Salah satu tata kelola teknologi informasi yang dapat dilakukan adalah dengan pengelolaan keamanan informasi yang terbaik. Evaluasi bertujuan untuk mengatur penggunaan TI, dan memastikan kinerja TI sesuai dengan tujuan/fokus utama area tata kelola TI, dimana teknologi informasi perusahaan berkaitan dengan para stakeholder yang berharap perusahaan dapat memberikan solusi TI dengan kualitas yang bagus, tepat waktu, dan sesuai dengan anggaran, menguasai dan menggunakan TI untuk mendatangkan value serta menerapkan TI untuk meningkatkan keamanan dan produktifitas sambil menangani risiko TI. Sehingga penerapan TI di perguruan tinggi akan dapat dilakukan dengan baik dengan suatu pengelolaan TI (IT Governance) dari mulai perencanaan sampai dengan pengelolaan implementasinya.

C. Peneliti dalam kaitannya sebagai pihak yang meneliti di Universitas Mitra Indonesia, melihat kebutuhan tersebut perlu dilakukan evaluasi terhadap pengelolaan keamanan informasi akademik dikarenakan terutama belum pernah dilakukan pengukuran keamanan informasi akademik menggunakan standar kerangka kerja (framework) COBIT 5.

D. Diharapkan kerangka kerja (framework) COBIT 5 ini dapat digunakan untuk membantu dalam tata kelola Teknologi Informasi yang sesuai standar, kebijakan dalam menjalankan operasi bisnis yang efektif dan efisien, serta memenuhi kebutuhan proses bisnis, maka dilakukanlah analisis dan evaluasi terhadap pengelolaan keamanan informasi akademik di lingkungan Universitas Mitra Indonesia dengan menggunakan standar kerangka kerja (framework) COBIT 5. 


\section{B. PEMBAHASAN / STUDI KASUS}

Berdasarkan masalah yang sedang diteliti dan tujuan yang hendak dicapai pada penelitian ini maka ditentukan tahapan-tahapan penelitian yang secara garis besar dapat dilihat pada gambar 1 .

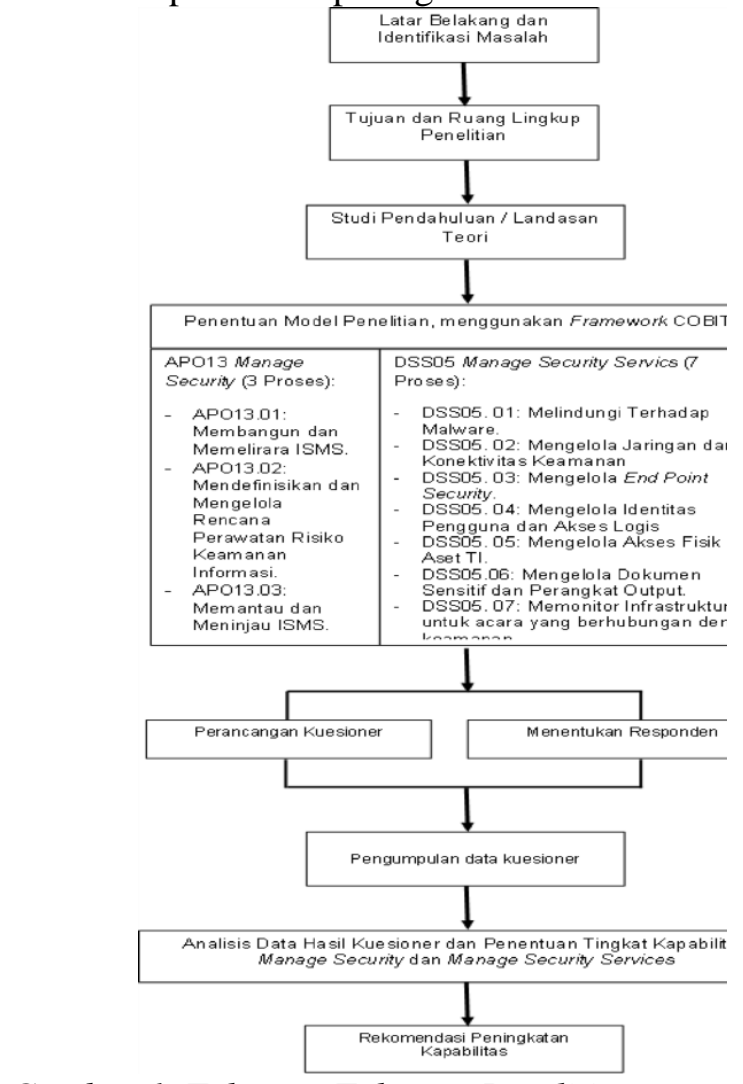

Gambar 1. Tahapan-Tahapan Penelitian Keterangan gambar:

1. Latar Belakang dan Identifikasi Masalah, Tujuan Penelitian dan Ruang Lingkup Penelitian yang teridentifikasi.

2. Studi Pendahuluan/Landasan Teori dilakukan untuk mengumpulkan semua data dan informasi dari berbagai jurnal, buku, laporan, artikel, dan data internet
3. yang berhubungan dengan obyek penelitian.

4. Penentuan Model Penelitian ditentukan dengan menggunakan kerangka kerja COBIT 5 yang dikeluarkan oleh IT Governance Institute and ISACA.

5. Metode Penelitian dengan melakukan survey pada STMIK Rosma Karawang dengan menggunakan metode kueisoner. Perancangan kuesioner dilakukan dengan berpedoman pada Proses Assessment Model dan Capability Model COBIT 5.

6. Kueisoner berupa kueisoner untuk mengetahui tingkat kapabilitas tata kelola sistem informasi yaitu berupa pertanyaan dengan jawaban Ya dan Tidak dan akan dibagaikan kepada pihak-pihak yang terkait.

7. Pemilihan Responden dilakukan pada seluruh bagian yang terdapat didalam struktur organisasi. Responden yang dipilih dalam penelitian ini adalah orang-orang yang dianggap mengetahui dan memahami sistem informasi yang sedang dijalankan oleh perusahaan tersebut sesuai arahan RACI (Resposible, Accountable, Consulted, Informed) chart.

8. Pengumpulan Data yaitu berupa data kuesioner yang telah diisi oleh responden.

9. Selanjutnya data kuesioner diolah dengan menggunakan perangkat lunak spreadsheet microsoft excel, kemudian dibuat grafik pencapaian tingkat capability (kapabilitas).

10. Dari hasil olah data kuesioner kemudian dianalisis penyajian analisis data akan dilengkapi dengan tabel sebagai pendukung analisis data kuantitatif. 
11. Dibuat laporan berupa laporan assessment, yang digunakan untuk melaporkan temuan dan rekomendasi usulan perancangan peningkatan tingkat kapabilitas pada manajemen.

12. Kesimpulan hasil penelitian dan saran.

\section{ID SECURITY}

QWTD4452377-ASP-5244166

\section{KESIMPULAN}

Beberapa hal dapat disimpulkan sebagai hasil dari penelitian yang dilakukan pada Universitas Mitra Indonesia (Umitra) berdasarkan audit sistem informasi berbasis web menggunakan COBIT 5.0 :

1. Hasil penilaian terhadap capability di STMIK Rosma Karawang untuk APO13.01 Membangun dan Memelihara ISMS, adalah sebesar $72 \%$ atau L (Largely Achieved) artinya ada bukti dari pendekatan yang sistematis, pencapaian signifikan, atribut yang didefinisikan dalam proses dinilai.

2. Hasil penilaian terhadap capability di Universitas Mitra Indonesia untuk DSS05.01 Melindungi Terhadap Malware, adalah sebesar $59 \%$ atau $\mathrm{L}$ (Largely Achieved) artinya ada bukti dari pendekatan yang sistematis, pencapaian signifikan, atribut yang didefinisikan dalam proses dinilai.

\section{E. DISKUSI}

COBIT 5 mendefinisikan APO13 memiliki 3 proses, antara lain: APO13.01 Membangun dan Memelihara ISMS, APO13.02 Mendefinisikan dan Mengelola Rencana Perawatan Risiko Keamanan
Informasi dan APO13.03 Memantau dan Meninjau ISMS. Pengukuran dari APO13 dihasilkan dari pengisian kuesioner yang disebarkan kepada responden berdasarkan Base Practice (BPs) dan Work Products (WPs) dari masing-masing proses tersebut.

\section{Analisis APO13.01 Membangun dan} Memelihara ISMS

Untuk aktifitas Membangun dan Memelihara ISMS (APO13.01):

1. Menentukan ruang lingkup dan batasan ISMS dalam hal karakteristik perusahaan, organisasi, lokasi, aset dan teknologi.

2. Mendefinisikan ISMS yang sesuai dengan kebijakan enterprise dan sejalan dengan enterprise, organisasi, lokasi, aset dan teknologi.

3. Menyelaraskan ISMS dengan pendekatan enterprise secara keseluruhan terhadap manajemen keamanan

4. Memperoleh autorisasi manajemen untuk mengimplementasikan dan mengoperasikan serta mengubah ISMS.

5. Menyiapkan dan memelihara penerapan pernyataan yang menggambarkan ruang lingkup ISMS.

6. Mendefinisikan dan mengkomunikasikan peran serta tanggung jawab manajemen keamanan informasi

7. Mengkomunikasikan pendekatan ISMS

\section{Analisis DSS05 (Manage Security Services)}

COBIT 5 mendefinisikan DSS05 memiliki 7 proses, antara lain : 
DSS05.01 Melindungi terhadap malware, DSS05.02 Mengelola jaringan dan keamanan konektivitas, DSS05.03

Mengelola keamanan endpoint, DSS05.04 Mengelola identitas pengguna dan akses logis, DSS05.05 Mengelola akses fisik ke aset TI, DSS05.06 Mengelola perangkat sensitif dan output, dan DSS05.07 Memonitor infrastruktur untuk acara yang berhubungan dengan keamanan. Jurnal Interkom Vol. 13 No. 3 Oktober 201834

Pengukuran dari DSS05 dihasilkan dari pengisian kuesioner yang disebarkan kepada responden berdasarkan Base Practice (BPs) dan Work Products (WPs) dari masing-masing proses tersebut

\section{F. REFERENCE}

[1] O. M. Febriani and A. S. Putra, "Sistem Informasi Monitoring Inventori Barang Pada Balai Riset Standardisasi Industri Bandar Lampung," J. Inform., vol. 13, no. 1, pp. 90-98, 2014.

[2] A. S. Putra, "Paperplain: Execution Fundamental Create Application With Borland Delphi 7.0 University Of Mitra Indonesia," 2018.

[3] A. S. Putra, "2018 Artikel Struktur Data, Audit Dan Jaringan Komputer," 2018.

[4] A. S. Putra, "ALIAS MANAGER USED IN DATABASE DESKTOP STUDI CASE DB DEMOS."

[5] A. S. Putra, "COMPREHENSIVE SET OF
PROFESSIONAL FOR DISTRIBUTE COMPUTING."

[6] A. S. Putra, "DATA ORIENTED RECOGNITION IN BORLAND DELPHI 7.0."

[7] A. S. Putra, "EMBARCADERO DELPHI XE 2 IN GPUPOWERED FIREMONKEY APPLICATION."

[8] A. S. Putra, "HAK ATAS KEKAYAAN INTELEKTUAL DALAM DUNIA TEKNOLOGY BERBASIS REVOLUSI INDUSTRI 4.0."

[9] A. S. Putra, "IMPLEMENTASI PERATURAN PERUNDANGAN UU. NO 31 TAHUN 2000 TENTANG DESAIN INDUSTRI BERBASIS INFORMATION TECHNOLOGY."

[10] A. S. Putra, "IMPLEMENTATION OF PARADOX DBASE."

[11] A. S. Putra, "IMPLEMENTATION OF TRADE SECRET CASE STUDY SAMSUNG MOBILE PHONE."

[12] A. S. Putra, "IMPLEMENTATION PATENT FOR APPLICATION WEB BASED CASE STUDI WWW. PUBLIKLAMPUNG. COM."

A. S. Putra,
"IMPLEMENTATION
SYSTEM FIRST TO INVENT
IN DIGITALLY INDUSTRY."
A. S. Putra, "MANUAL
REPORT \& INTEGRATED
DEVELOPMENT
ENVIRONMENT BORLAND
DELPHI 7.0."

[15] A. S. Putra, "PATENT AS 


\author{
RELEVAN \\ RESEARCH." \\ SUPPORT \\ [16] A. S. Putra, "PATENT FOR \\ RESEARCH STUDY CASE \\ OF APPLE. Inc." \\ [17] A. S. Putra, "PATENT \\ PROTECTION \\ FOR \\ APPLICATION INVENT." \\ [18] A. S. Putra, "QUICK REPORT \\ IN \\ PROGRAMMING." \\ [19] A. S. Putra, "REVIEW \\ CIRCUIT LAYOUT \\ COMPONENT \\ REQUIREMENT ON ASUS \\ NOTEBOOK." \\ [20] A. S. Putra, "REVIEW \\ TRADEMARK PATENT FOR \\ INDUSTRIAL \\ TECHNOLOGY BASED 4.0." \\ [21] A. S. Putra, "TOOLBAR \\ COMPONENT PALLETTE IN \\ OBJECT \\ ORIENTED \\ PROGRAMMING." \\ [22] A. S. Putra, "WORKING \\ DIRECTORY SET FOR \\ PARADOX 7." \\ [23] A. S. Putra, "ZQUERY \\ CONNECTION \\ IMPLEMENTED \\ PROGRAMMING \\ STUDI \\ CASE PT. BANK BCA Tbk." \\ [24] A. S. Putra, D. R. Aryanti, and \\ I. Hartati, "Metode SAW \\ (Simple Additive Weighting) \\ sebagai Sistem Pendukung \\ Keputusan Guru Berprestasi \\ (Studi Kasus: SMK Global \\ Surya)," in Prosiding Seminar \\ Nasional Darmajaya, 2018, vol. \\ 1, no. 1, pp. 85-97. \\ [25] A. S. Putra and O. M. Febriani, \\ "Knowledge Management \\ Online Application in PDAM \\ Lampung Province," in
Prosiding International Technology and Business (ICITB), 2018, pp. 181-187. \\ conference on Information \\ [26] A. S. Putra, O. M. Febriani, and \\ B. Bachry, "Implementasi \\ Genetic Fuzzy System Untuk \\ Mengidentifikasi Hasil Curian \\ Kendaraan Bermotor Di Polda \\ Lampung," SIMADA (Jurnal \\ Sist. Inf. dan Manaj. Basis \\ Data), vol. 1, no. 1, pp. 21-30, \\ 2018. \\ [27] A. S. Putra, H. Sukri, and K. \\ Zuhri, "Sistem Monitoring \\ Realtime Jaringan Irigasi Desa \\ (JIDES) Dengan Konsep \\ Jaringan Sensor Nirkabel," \\ IJEIS (Indonesian J. Electron. \\ Instrum. Syst., vol. 8, no. 2, pp. \\ 221-232. \\ [28] D. P. Sari, O. M. Febriani, and \\ A. S. Putra, "Perancangan \\ Sistem Informasi SDM \\ Berprestasi pada SD Global \\ Surya," in Prosiding Seminar \\ Nasional Darmajaya, 2018, vol. \\ 1, no. 1, pp. 289-294.
}

